\title{
APPOINTMENT OF COUNSEL FOR A DEFAULTING CORPORATION IN A CRIMINAI PROCEEDING
}

Rule forty-three of the Federal Rules of Criminal Procedure $^{\mathbf{1}}$ provides that a defendant shall be present at every stage of his trial. A corporation, under this rule, "may appear by counsel for all purposes." Acting within the context of this rule, a federal district court has recently decided that it "must ... have power to appoint" an attorney to represent a summoned corporation that has defaulted in appearance. United States v. Crosby ${ }^{2}$ involved the criminal prosecution of several individuals and a bankrupt corporation on a general conspiracy charge involving questions of fraudulent mail and telephone communications and the sale of unregistered stock in violation of Securities and Exchange Commission regulations. ${ }^{3}$ When the corporation defaulted in appearance after summons, the United States moved that "someone be appointed" to represent the corporation.

In concluding that it had the power to appoint an attorney in this situation, the district court reasoned that, because the corporation had to be present and could only be present if it were represented by an attorney, "judgment of conviction . . . after a trial where it had not appeared by counsel would therefore be invalid."" That the court had capacity to render a valid judgment was "not open to question," because, if it could not render judgment, the provision for summoning a corporation would be purposeless.

There is no reported precedent for the problem presented in the Crosby case. 5 Moreover, the question of appointing counsel for a de-

\footnotetext{
$x$ "The defendant shall be present at the arraignment, at every stage of the trial including the impaneling of the jury and the return of the verdict, and at the imposition of sentence, except as otherwise provided by these rules.... A corporation may appear by counsel for all purposes. In prosecutions for offenses punishable by fine or by imprisonment for not more than one year or both, the court, with the written consent of the defendant, may permit arraignment, plea, trial and imposition of sentence in the defendant's absence. ..." FED. R. CRIM. P. 43.

${ }^{3} 24$ F.R.D. 15 (S.D.N.Y. 1959).

${ }^{3}$ These issues, which do not appear in the report of the decision, were supplied by a letter to the Duke Law Journal, February I8, 1960, from Thomas F. Burchill, Jr., the attorney appointed by the court in this case.

24 F.R.D. at $15-16$.

"Judge Dimock, in his opinion in the instant case, observed that "This is one of those oft occurring cases where a fundamental question arises which must have been
} 
faulting corporation in a criminal proceeding is not analogous to the cases dealing with the appointment of counsel for indigent individual criminal defendants. In such cases it is settled that no individual is required to have the assistance of counsel if he chooses to present his own defense. ${ }^{6}$ The question that goes to the root of the present case, however, is whether a corporation may ever appear except by legally qualified counsel.

The unanimous view, both under the common law and the modern cases, is that a corporation is incapable of appearing personally in any action ${ }^{7}$ because it can act only through its agents. Furthermore, the

answered over and over again but where no reported decision can be found which gives the answer." 24 F.R.D. 15.

"The right to counsel in the federal courts is grounded in the sixth amendment: "In all criminal prosecutions, the accused shall enjoy the right ... to have the assistance of counsel for his defence." U.S. ConsT. amend. VI. This provision has been construed as not being limited to the privilege of being represented by counsel, but as including the right to have qualified counsel assigned if a defendant, for financial or other reason, is unable to secure counsel. Johnson v. Zerbst, 304 U.S. $45^{8}$ (1938). However, the right may be waived by an individual defendant, although the waiver must be "intelligent and competent." Id. at 465. The United States Code provides: "In all courts of the United States the parties may plead and conduct their own cases personally or by counsel, as, by the rules of such courts, respectively, are permitted to manage and conduct causes therein." $6_{3}$ Stat. $10_{3}$ (1949). 28 U.S.C. $\$ 1654$ (1958). See generally, on the right to counsel in federal courts, BEANEr, THE RIGHT To Counsel in AMERican Courts chs. 3 \& 5 (1955); Feliman, The Defendant's Rights ch. 7 (1958).

The state courts present a somewhat different situation since the right to counsel under the sixth amendment is not necessarily rendered binding on the states by the fourteenth amendment. A majority of the Supreme Court continues to follow Betts v. Brady, 316 U.S. 455 ( 1942 ), and uphold an unqualified right to counsel in state courts only in capital prosecutions and in those non-capital prosecutions where there are particular circumstances indicating injustice or unfairness as a result of a defendant's inability to obtain counsel. See, for example, Cash v. Culver, 358 U.S. 633 (1959) and cases cited therein. Even in those cases where a defendant has the right to have counsel appointed in state courts, however, the right may be waived, although the Supreme Court may question the validity of the waiver. Moore v. Michigan, 355 U.S. 155 (1957). For a general treatment of the right to counsel in state courts, see BEANEY, op. cit. supra note 6, chs. 3 \& 4; Fellman, The Federal Right to Counsel in State Courts, 3 I NEB. L. REv. 15 (1951).

${ }^{7}$ Heiskell v. Mozie, 82 F.2d 86I (D.C. Cir. 1936) (dictum); MacNeil v. Hearst Corp., 160 F. Supp. I57 (D.C. Del. 1958); Brandstein v. White Lamps, Inc., 20 F. Supp. 369 (S.D.N.Y. 1937); Paradise v. Nowlin, 195 P.2d 867 (Cal. App. 1948); Bennie v. Triangle Ranch Co., 73 Colo. 586, 216 Pac. 718 (1923); Nispel v. Western Union R.R., 64 Ill. 3 II ( 1872 ); Kankakee Drainage Dist. v. Comınissioners, 29 Ill. App. 86 (1887); Clark v. Austin, 340 Mo. 467, 10r S.W.2d 977 (1937); New Jersey Photo Engraving Co. v. Carl Schonert \& Sons, Inc., 95 N.J. Eg. 12, 122 Atl. 307 (1923); Black \& White Operating Co. v. Grosbart, I07 N.J.L. 63, 151 Atl. 630 
vast majority of courts have adhered to the rule that the agent through whom the corporation must appear must be a duly qualified attorney. Such a rule, of course, prohibits a corporate officer or employee who is not an attorney from representing the corporation in litigation. None of these decisions, however, involved a criminal prosecution.

The traditional rationale for the view that only an attorney may represent a corporation in court is that a corporation is "an artificial entity created by law" and as such cannot act as a natural person in presenting its own case or representing itself in court. ${ }^{9}$ A more meaningful justification is that such a rule prevents "unscrupulous laymen and disbarred attorneys from maintaining a flourishing practice under the cloak of being corporate officers." 10 For example, unfortunate defendants might be subject to the severe harassment of groundless, malicious suits by a corporate plaintiff whose litigation agents were not bound by the ethical restraints placed on the legal profession; large scale "law" practice by corporate agents might, to a degree, render

(x930); Aberdeen Bindery, Inc. v. Eastern States Printing \& Publishing Co., Inc., I66 Misc. 904, 3 N.Y.S.2d 419 (App. T. 1938); Mortgage Comm'n v. Great Neck ImpCo., 162 Misc. 416,295 N.Y.S. 107 (Sup. Ct. 1937); J. T. Whalen, Inc. v. Pritzert, 167 Misc. 471, 3 N.Y.S.2d 418 (N.Y. City Ct. 1937); Culpeper Nat'l Bank v. Tidewater Imp. Co., 119 Va. 73, 89 S.E. I18 (1916).

${ }^{8}$ Osborn v. United States Bank, 22 U.S. (9 Wheat.) 738,830 (1824) (dictum); Mullin-Johnson Co. v. Penn Mutual Life Ins. Co., 9 F. Supp. 175 (D.C. Cal. x934). See also the cases cited in note 7, supra; 9 Fletcher, Private Corporations $\$ 4463$ (perm. ed. 1931) Supp. 1959. Contra, A. Victor \& Co. v. Sleininger, 255 App. Div. 673, 9 N.Y.S.2d 323 (1939); Sellent-Repent Corp. v. Queens Borough Gas \& Elec. Co., 160 Misc. 920 , 290 N.Y.S. 887 (Sup. Ct. 1936); Milmoe v. Meyer, 15 N.Y.S.2d 899 (Madison County Ct. 1939); roth St. \& 5th Inc. v. Naughton, I63 Misc. 437, 296 N.Y.S. 952 (N.Y. City Ct. 1937).

${ }^{\circ}$ Paradise v. Nowlin, I95 P.2d 867 (Cal. App. 1948) and cases cited therein. Expanding this rationale, one commentator has suggested that, because a natural person who does not choose to represent himself cannot be represented by other than a licensed attorney, a corporation, that acts only through agents, should not be given a more favored position. 7 BrookLYY L. REv. 371, 375 (1938). It seems questionable, however, whether reliance on the archaic notion of corporate disability is any aid to legitimate analysis.

${ }^{10} s_{7}$ U. PA. L. REv. 1006, 1007 (1939). See, e.g., Mortgage Comm'n. v. Great Neck Imp. Co., 162 Misc. 416, 295 N.Y.S. 107 (Sup. Ct. 1937). This objection has been termed "more theoretical than substantial." A. Victor \& Co. v. Sleininger, 255 App. Div. $673,676,9$ N.Y.S.2d 323, 326 (1939).

There is also the contention that, even aside from actual litigation, the corporation has already been allowed to take away too much of the lawyer's business. As early as 1913 one distressed attorney was concerned that, "The lawyer, as such, is being devoured by his own Frankeinstein." Bristol, Passing of the Legal Profession, 22 YALE. L.J. $590,613(1913)$. 
meaningless the requirement of legal training before admission to practice before the bar.

Yet, it is questionable whether there is any real justification for a rule that prohibits a corporation from performing for itself the legal services that an individual is allowed to perform on his own behalf. It has been quite properly suggested that the rule is particularly harsh in its application to financially weak corporations that might forego action on a meritorious small claim rather than pay the consequent attorney's fees. ${ }^{11}$ Even a corporation with a large claim, that it believed to be legitimate, might find itself denied its day in court because it could find no lawyer who would take the case. ${ }^{12}$ One commentator has observed that the courts have "inherent power to regulate the practice of law"13 and that any real evil that might emerge as a result of litigation in the hands of agents who were not subject to the ethical standards of members of the bar could be controlled by the expedient of contempt proceedings.

The question of restricting the conducting of corporate litigation to members of the legal profession is best put in perspective when it is regarded as a "problem of using the processes of the law to define and protect a monopoly."14 A monopoly must, in the final analysis, be beneficial to society in order to justify its continuing existence. Mr. Justice Cardozo observed that "The tendency of a principle to expand itself to the limit of its logic may be counteracted by the tendency to confine itself within the limits of its history."15 A beneficial application of this thesis is demonstrated by the situation presented by the instant case. It is submitted that the court followed blindly what it considered to be precedent and that in so doing it failed to reckon with policy factors that call for a different result.

In determining that the defendant corporation could appear only by an attorney in this criminal proceeding, the court was following the precedent of civil actions. The danger of ill-conceived, unscrupulous, harassing suits, which, to a degree, socially justifies sustaining the monopoly of the legal profession in corporate civil litigation, is not present where the corporation is defending a criminal prosecution.

\footnotetext{
${ }^{11}$ A. Victor \& Co. v. Sleininger, supra note 10, at 326; 8 BrookLYN L. REv. 351 , 353 (1939).

${ }^{13}$ A. Victor \& Co. v. Sleininger, supra note ro.

${ }^{13} 8$ 7 U. PA. L. REv. 1006, 1007.

14 Llewellyn, The Bar's Troubles, and Poultices-and Cures?, 5 LAW \& ConTEMP. Prob. 104 ( 1938 ).

${ }^{15}$ Cardozo, The Nature of the Judicial Process 5 I (192 I).
} 
Moreover, there is not the opportunity that there is in civil actions for an extensive practice of law by legally untrained corporate officials. ${ }^{16}$

The interests of society are properly served as long as the corporate defendant is present in criminal proceedings to present its defenses. It is hard, unjustified law that, for example, forces a corporation to the expense of engaging an attorney even if it wishes only to plead guilty to a criminal charge. No good reason appears for not allowing an officer of a corporation to appear and defend on the corporation's behalf. The officer, as an individual, could be made to appear, assuring the "presence" of the corporate defendant, and there is an identity of interest in the corporation, as such, and its officers that should insure the presentation of an adequate defense. This identity of interest differentiates the case of the corporate defendant from that of the individual defendant, who, under settled law, must be represented by a qualified attorney, if he does not wish to act as his own counsel.

In its practical application, this solution should not materially alter the present function of the legal profession in defending corporations in criminal proceedings. The employment of an attorney would be on the same basis as it is for an individual defendant. If the officer representing the corporation should feel the need of legal assistance in providing an adequate defense to the charge, the corporation would be at liberty to employ attorneys. Moreover, should the corporation be unable to employ counsel, a court would be free to handle an appointment as it would in the case of an individual defendant.

Appointment of counsel to represent a criminal defendant was never conceived of as a means of placing the defendant before the court; it should not now be so construed. If the corporation does not wish to employ counsel, it should not be forced to do so absent some compelling social justification. Unquestionably, the court in the instant decision was correct in assuming that it must have power to bring the defendants before it ${ }^{17}$ unfortunately, it was incorrect in its choice of methods to accomplish that end. The court, therefore, has allowed its logic to carry it to an undesirable result.

\footnotetext{
${ }^{10}$ There is, of course, the possibility that a corporation might attempt to make a disbarred but able shyster a temporary corporate officer. It would seem, however, that a court should have adequate control over such a practice through contempt proceedings.

${ }^{17}$ Since the defendant corporation was a bankrupt, it is possible that the court in the instant case might have obtained the "presence" of the corporation through the trustee in bankruptcy, although the problem of the trustee's defending a criminal prosecution against the bankrupt does not appear to have arisen previously. I CoLliER, BANKRUPTCY $\$$ I1.09 (14th ed. 1956).
} 